\title{
Assessment of the Energy Potential of Municipal Solid Waste (MSW) in Freetown, Sierra Leone
}

\author{
Andy Otis Ngegba ${ }^{1}$, Akopon J. Bertin ${ }^{2}$ \\ ${ }^{1}$ Notre Valeur Resource to Treasure (NoVReT) SL. Ltd., Freetown, Sierra Leone \\ ${ }^{2}$ ICAP at Columbia University, New York, USA \\ Email: andyngegba@gmail.com, akoponbertin@gmail.com
}

How to cite this paper: Ngegba, A.O. and Bertin, A.J. (2020) Assessment of the Energy Potential of Municipal Solid Waste (MSW) in Freetown, Sierra Leone. Open Access Library Journal, 7: e5902.

https://doi.org/10.4236/oalib.1105902

Received: November 5, 2019

Accepted: January 6, 2020

Published: January 9, 2020

Copyright $\odot 2020$ by author(s) and Open Access Library Inc.

This work is licensed under the Creative Commons Attribution International License (CC BY 4.0).

http://creativecommons.org/licenses/by/4.0/

\begin{abstract}
Electricity supply in Freetown has been unreliable partly due to lack of sustainable alternative generation sources, and the city is beset by poor waste management system, which has led to indiscriminate waste disposal since the end of the country's civil war in 2002, contributing to air and water pollution. This necessitates the need for research and development on Waste-to-Energy (WtE) technologies. Waste generation was estimated using population data from Statistics Sierra Leone (SSL), and analysed using reasonable assumptions and theories based on previous studies, and information on waste generation per capita was collected from publications and grey literatures. Energy potential was estimated from the amount of waste by component and their fuel characteristics to calculate the Lower Calorific Value (LCV) for each waste category. The weighted LCV of each waste component was then calculated and added to get the LCV of the overall waste stream. The study revealed that with the population of Freetown estimated at about 1,200,000, and a waste generation per capita per day of $0.5 \mathrm{~kg}$, at least 600 metric tons of waste could be generated per day or 219,000 metric ton of waste annually. About $83 \%$ of this waste is combustible, and with an overall (LCV) of 6.4 $\mathrm{MJ} / \mathrm{kg}$, the energy potential was estimated at $398.2 \mathrm{kWh}$ per ton of waste, (enough to meet the electricity needs of about 50 Freetown homes in one day). This result could inform policy makers and developers that the energy sector of Sierra Leone and other developing countries with similar waste characteristics could be diversified by utilising waste resources.
\end{abstract}

\section{Subject Areas}

Industrial Engineering, Mechanical Engineering 


\section{Keywords}

Electricity Generation, Lower Calorific Value (LCV), Waste Management, Waste-To-Energy, Freetown, Population, Waste Generation Per Capita

\section{Introduction}

The shocking statistics on electricity access and poor waste management system have been crucial challenges in Sierra Leone that motivated this study on Waste-to-Energy ( $\mathrm{WtE}$ ), a concept of utilising the energy potential of waste to produce heat, electricity and biogas. It is an alternative means of electricity generation capable of gradually reducing the need for waste disposal on uncontrolled dumpsites [1]. Various methods of converting MSW into energy are used depending on energy requirement, waste availability, composition and characteristics, but they are all based on two fundamental principles; firstly, by burning waste to generate heat that is used to convert water into steam, which drives a steam turbine to produce electricity, which is also referred to as a thermochemical process, and secondly by converting waste into gas or biofuel, referred to as a biochemical process [2]. MSW in this context refers to the waste collected from households, public institution, schools, and commercial premises that are disposed of on dumpsites excluding human feces [3]. Energy production in Sierra Leone has been focused mainly on electricity generation from fossil fuels, solar and hydro power plants for lighting up homes, commercial institutions and some industries, but there has not been any waste-to-energy facility.

The need for sustainable means of producing energy to meet the growing energy demand around the world has attracted research interests on the energy potentials of various kinds of waste, and there have been growing interests in recovering the energy potentials from MSW, which has been considered as an effective way of reducing residual waste, with the added benefit of providing renewable energy to supplement conventional supplies [4]. Although there have been efforts in conducting research on WtE potentials in Africa, article publications and grey literature that have focused on the same in Sierra Leone are almost non-existent. This absence of literature on waste-to-energy in Sierra Leone motivated this study, which sets to contribute to our understanding of how waste could be utilised to improve electricity generation capacity in Freetown and how WtE could gradually eliminate the need for uncontrolled dumpsites in the capital city. This could be the first evidence-based research to focus entirely on utilising waste resources to complement other sources of grid electricity in Sierra Leone that could raise awareness for energy stakeholders to focus on $\mathrm{WtE}$ for the improvement of the country's energy sector. The scope of this paper was to assess the MSW situation in Freetown in terms of volume and composition and to determine how much energy could be recovered from it on a daily basis. 
Freetown was chosen because it is the capital city of Sierra Leone, where uncontrolled waste disposal has damaged its aesthetic value much to the inconvenience of its inhabitants. Freetown also experiences irregular electricity supply that has been forcing businesses and public institutions to always prepare for power cuts and rationing of electricity supply.

Limited access to energy is not only an obstacle to industrialization; it also reduces attraction to local and foreign investment, and severely affect productivity, educationally and economically. The World Bank Sustainable Energy for All database on access to electricity revealed that only about $23.4 \%$ of Sierra Leone's population has access to grid electricity [5], one of the worst in the world, and the 2019 Energy Progress Report revealed that less than 10\% of Sierra Leone's population have access to clean cooking fuels and technologies [6]. About $80 \%$ of the energy supply in Sierra Leone comes from biomass, but consumed through inefficient burning of mainly firewood and charcoal for cooking [7]. According to the 2015 population and housing census, $64.7 \%$ of households rely on firewood for cooking, $32.1 \%$ uses charcoal while the other sources including gas, kerosene, electricity, etc. account for only 3.2\% [8].

A major challenge in addressing limited access to electricity is the lack of commitment in utilising alternative energy sources that are also environmentally friendly to diversify our energy sector, one of such resource is Municipal Solid Wastes (MSW). This lack of commitment is directly linked with weak and ineffective energy and environmental policies that could lead to research and development towards alternative sources of energy. In 2013, it was recorded that about 900 - 1000 metric ton of unsorted waste was generated in Freetown per day, but only about $40 \%$ was collected and disposed in two recognised but uncontrolled dumpsites [9]. The waste collected and disposed on these dumpsites will accumulate and eventually lead to environmental degradation through the release of contaminants including greenhouse gases.

The energy potential of a fuel is a measure of its Calorific Value [10]; the amount of energy released in Joules (J) from the combustion of a unit weight of waste, measured in J/kg [11]. Thus, the Lower Calorific Value (LCV) and not the Higher Calorific Value (HCV) is required to determine the energy potential of MSW because waste develops HCV if the latent heat of steam is recovered as in calorimeter experiments, but for normal combustion, the LCV is obtained because the latent heat is lost when water leaves as steam. The calorific value is influenced by waste composition and characteristics such as moisture and combustible content, as shown in Table 1, which makes the energy potential vary from one country to another. For the MSW to be suitable for combustion the overall LCV should always be at least between $6-7 \mathrm{MJ} / \mathrm{kg}$ [12]. In the case of coal fuel, a typical value is approximately $30 \mathrm{MJ} / \mathrm{kg}$ while for oil; the value is about $40 \mathrm{MJ} / \mathrm{kg}$. These values can be compared with that for MSW of about $10 \mathrm{MJ} / \mathrm{kg}$, which has increased about $20 \%$ since the early 1970 s, because of factors such as the decreasing quantity of ash in the waste from coal fires, and the increasing 
Table 1. Typical fuel characteristics of solid waste components and energy potential [12].

\begin{tabular}{|c|c|c|c|c|c|c|c|}
\hline Component & Moisture $\% W$ & Ash $\% A$ & $\begin{array}{c}\text { Combustible } \\
\% C\end{array}$ & $\begin{array}{c}H_{\text {awf }} \\
(\mathrm{kJ} / \mathrm{kg})\end{array}$ & $\begin{array}{c}H_{\text {low }} \\
(\mathrm{kJ} / \mathrm{kg})\end{array}$ & $\begin{array}{c}\text { Electrical } \\
\text { energy equivalent } \\
(\mathrm{kWh} / \mathrm{kg})\end{array}$ & $\begin{array}{c}\text { Energy in } \\
\text { a year } \\
(\mathrm{kWh} / \mathrm{kg})\end{array}$ \\
\hline $\begin{array}{c}\text { Food and organic waste } \\
\text { (to be analyzed in each case) }\end{array}$ & 66 & 13 & 21 & 20,000 & 2586 & 0.718 & 6293 \\
\hline Paper and cardboard & 47 & 6 & 47 & 19,000 & 7781 & 2.161 & 18,933 \\
\hline Rubber and leather & 11 & 26 & 63 & 25,000 & 15,481 & 4.300 & 37,671 \\
\hline Textiles & 33 & 4 & 63 & 19,000 & 11,163 & 3.101 & 27,164 \\
\hline Wood & 35 & 5 & 60 & 19,000 & 10,544 & 2.929 & 25,658 \\
\hline Glass & 3 & 97 & 0 & 0 & -73 & -0.020 & -178 \\
\hline Metal & 6 & 94 & 0 & 0 & -147 & -0.041 & -357 \\
\hline Inert & 10 & 90 & 0 & 0 & -245 & -0.068 & -595 \\
\hline Fines $(<12 \mathrm{~mm}$ mesh $)$ & 32 & 46 & 22 & 15,000 & 2518 & 0.699 & 6126 \\
\hline Polystyrene (wrapping) & 29 & 8 & 63 & 40,000 & 24,491 & 6.803 & 59,595 \\
\hline
\end{tabular}

proportion of dry packing material [10]. Table 1 shows the typical ash and water free CVs (Hawf) of solid waste components, and Equation (1) shows how the LCV is calculated when Hawf is known [12]. Equation (1) shows that the LCV increases with increase in the combustible fraction and decreases if the moisture content increases. Maintaining the LCV is therefore crucial in ensuring a stable energy output.

Analysis by [12] and [13] produced results that show the typical theoretical energy potential of $1 \mathrm{~kg}$ of various components of MSW as shown in Table 1. For every $1 \mathrm{~kg}$ of food and organic waste, $0.718 \mathrm{kWh}$ of electrical energy could be produced, which will amount to $17.24 \mathrm{kWh}$ per day (24 hours). Assuming the average consumption of homes in Freetown is $6 \mathrm{kWh}$ per day, this could provide the electricity needs of a home for about three (3) days.

$$
H_{\text {low }}=H_{\text {awf }} * C-2445 * W(\mathrm{~kJ} / \mathrm{kg})
$$

$H_{\text {low: }}$ LCV.

$H_{\text {awt }}$ Ash and water free $\mathrm{C}$.

$C$ : Combustible fraction.

$W$ : Moisture content.

Different studies have produced various estimates of the energy potentials of MSW. Reference [14] assessed the waste-to-energy potential in middle income countries of Middle East and North Africa (MENA) by evaluating multiple waste management scenarios involving incineration and anaerobic digestion, in which the average Lower Heating Value was estimated at $14.2 \mathrm{MJ} / \mathrm{kg}$, giving an energy potential of $597 \mathrm{kWh}$ per ton of incinerated waste by total mass-burning, while for the incineration by non-recyclable mass-burning scenario, the energy potential was about $545 \mathrm{kWh}$ per ton of incinerated waste. The estimated energy potential was higher in a study conducted by [15], in which mathematical models 
were used to estimate the energy recovery and biogas generation potentials and concluded that, by thermochemical processes, the estimated energy potential was $5970 \mathrm{kWh}$ per ton of MSW, and $62 \mathrm{kWh}$ per ton of MSW by using biochemical processes. An assessment at the African level revealed that the electricity production potential from the total waste generated in Africa was $62.5 \mathrm{TWh}$ in 2012 and could increase up to 122.2 TWh in 2025, but by considering the actual waste collected, the potential was estimated at 34.1 TWh in 2012 and projected to reach $83.8 \mathrm{TWh}$ in 2025 [16].

Despite the differences in energy potentials estimated by various studies, some of which were cited above, there is an indication that energy from waste could be an integral part of the energy mix in Africa. The barriers that hinder the adoption of WtE technologies have been discussed extensively in literature, and according to [17], "the critical barriers are poor institutional framework and infrastructure, weak environmental policies, inadequate planning policies, non-implementation of existing policies, and lack of coordination and linkages in WtE programs". Other key issues are high initial capital cost of installation and lack of skilled human resource. According to a review by [17], important lessons for successful WtE programs have been categorized under four principal areas: enacting energy and environmental policies, rolling out economic and financial policies, and promoting research and development. Reference [18] asserted that the commitment of governments and their ministries/agencies in charge of energy, agriculture, science, technology, environment and local government are of the utmost importance to the promotion of WtE projects in Africa, by making proper long-term objectives with appropriate planning and strategies for WtE development on the continent [19].

WtE by combustion has been the focus of this study because it has proven to be a suitable alternative to the use of conventional fossil fuels to generate heat and electricity [3] in a good number of European countries since the end of the nineteenth century, and is capable of reducing waste volume by $90 \%$ [12]. In a review of municipal solid waste-to-energy trends in the USA by [20], it was highlighted that there are regional contrasts on technology adoption, unique challenges of each technology, commonly used decision support tools, and major operators, and only about 13\% of MSW is used for energy recovery and 53\% is landfilled. Nonetheless, it was concluded that adoption of thermal WTE technologies in US could continue to increase, albeit slowly, in coastal and urban areas lacking suitable lands for new landfills. There are about $492 \mathrm{WtE}$ plants operating in Europe not including harzadous waste incineration plants, thermally treating about 96 million metric ton of waste, with the leaders being France with 126 WtE plants, Germany, 96, UK, 40, Italy, 39, and Sweden, 34, etc. [21]. According to United Nations Environment, the amount of waste incinerated for energy recovery represents about 25\% of MSW generated in Europe [22], but this number of WtE plants in Europe is expected to increase as the search for alternatives to fossil fuel-based energy intensifies. In Africa, a 500-metric ton per 
day of MSW biogas facility was opened in South Africa in January 2017, which has been referred to as the first major WtE facility in Africa [23], and in Ethiopia, a $50 \mathrm{MW}$ WtE facility has commenced operation in 2018, converting about $80 \%$ of the city's waste that would have otherwise ended up on uncontrolled dumpsites into electricity to provide the electricity needs of $30 \%$ of households in Addis Ababa [22]. There has also been some commitment demonstrated in some African countries through ongoing research and development work for the establishment of WtE by combustion facilities.

To this end, as Sierra Leone has struggled for a stable economy, proper waste management system, and stability in electricity supply, it is important to find a cheaper and more reliable means of generating electricity. Energy from waste will not only increase the electricity generation capacity in Sierra Leone, it will provide the much-needed waste management solution in Freetown, and will contribute to the development of a circular economy system [24]. A system wherein resources are kept in use for as long as possible, their maximum value extracted, and then recover and regenerate products and materials at the end of their service life [25], as opposed to the make, use and dispose or linear economy system.

\section{Materials and Methods}

\subsection{Data Collection and Analysis}

The method for the estimation of energy potential of waste is dependent on the type of conversion technology. In this paper, the estimation was done for WtE by combustion because of its capability to reduce waste volume while directly producing electricity. The method used to collect data was by reviewing existing literature, observation, and studying reports from institutions working on waste management technologies. The analysis of the solid waste situation in Freetown was done based on reasonable assumptions and estimations, theories, previous studies and information from industries due to lack of data from local waste management authorities, which is an established method according to [26]. Data from population and housing census, previous studies on waste management in Sierra Leone, and information on waste generation per capita from publications by international agencies were also used. The estimation was done to obtain the trend of waste generation from 2004 and projected up to 2027, using a population growth rate according to Statistics Sierra Leone. The year 2004 was chosen because a study was conducted by [27], in which waste generation per capita was estimated to be $0.45 \mathrm{~kg}$ per capita per day, but had the possibility of increasing due to economic growth and improved living standard. A projection of waste generation was done up to 2027 to get a medium-term knowledge of the situation, as well as what the worst case could be by examining three scenarios, which are described in section four. Data on waste composition according to a study by [28] was used to determine the overall LCV of the waste, a key factor for the de- 
termination of the energy potential, similar to the method used in a study that investigated WtE potential in the Eastern Region of Saudi Arabiaby [29], in which population forecasting and rate of production of MSW were used to estimate the $\mathrm{WtE}$ potential. The method of estimating waste generation based on population and economic growth was also supported by the observation in a study by [30], a subsequent increase in MSW was observed with urban migration rate increasing annually and a simultaneous growth in population and Gross Domestic Product (GDP). Additionally, economic development and urbanisation have contributed directly to a rapid increase in municipal solid waste generation in China according to [31], which by 2014 was estimated to be 178.6 million metric tons.

\subsection{Assessment of Municipal Solid Waste (MSW) in Freetown, Sierra Leone}

Freetown is the capital city of Sierra Leone, with a population of about 1,200,000, and has experienced an average annual growth rate of $4.2 \%$ between 2004 and 2015 [8], mainly attributed to the high rate of urbanization after 2002 (the end of the 10-year civil war). Studies have suggested that solid waste generation is proportional to the population as well as economic prosperity. Reference [32] explored the possibilities of energy generation from MSW in India and asserted that "the greater the economic prosperity and higher the proportion of urban population, the greater is the amount of solid waste produced".

The GDP of Sierra Leone increased by 300\% between 2002 and 2014 [33] as the country attracted a good number of international development aids and foreign investments that led to more job opportunities and a change in the lifestyle of some people. At some point during this period, the country was among the world's fastest growing economies before the EBOLA outbreak in 2014, and the sudden decline in iron ore prices. This affected economic development as the GDP dropped by $29.1 \%$ [33]. This and other potential national issues that will either affect the country positively or negatively and eventually affect population size and waste generation per capita were the basis for the examination of the three scenarios described in Section 3.

\subsubsection{Waste Composition}

The composition of waste is very crucial in waste management, as it affects the density of the waste, proposed collection, transportation and disposal methods, and calorific value. Thus, it is necessary to determine the strategy for waste reuse, reduction and recycling [28]. The components of MSW changes with standards of living. Wastes generated in low and middle-income cities for instance have a large proportion of organic waste, mostly over $50 \%$ of the total waste generated [28], whereas the waste in high-income cities is more diversified with relatively more plastics and paper [26]. Reference [28], in assessing solid waste management in Freetown, used a door-to-door survey approach to determine 
the rate of solid waste generation and their composition through sorting and weighing, in which it was revealed that organic wastes accounted for about $69 \%$ of the total wastes generated in four zones in Freetown, as shown in Figure 1.

\subsubsection{Estimation of Lower Calorific Value (LCV) of Municipal Solid Waste (MSW) in Freetown}

The LCV, also known as the heating value of waste, is dependent on the location from which the waste is generated, and as such, the determination of LCV for the waste in Freetown required an analysis on how much of the waste components is generated and their characteristics to get the energy potential. Fuel characteristics of solid waste as in Table 1, and waste composition as in Figure 1 according to [28] were used to estimate the overall LCV of the waste in Freetown. Equation (1) was used to calculate the LCV for each category of waste as shown in Table 1 giving the values of LCV (MJ/kg) in Table 3. The category denoted as others was assumed to include rubber, textile, leather, and wood. The weighted LCV of each waste component was then calculated using the percentage of total waste as shown in Figure 1 to get the final results in Table 3. The overall LCV was obtained by adding all the weighted values of LCV.

\section{Results}

\subsection{Estimation of Waste Generation in Freetown}

The three scenarios and the results obtained in the estimation of waste generation are described in this section.

Scenario 1 population growth rate remains at $4.2 \%$

Based on a gradual increase in waste generation per capita and a constant population growth rate of $4.2 \%$, the waste generation per capita was estimated to grow as shown in Figure 2. The amount of unsorted waste generated in 2004 was estimated at 348 metric tons per day (TPD) or 127,020 metric tons annually; it increased to 660 TPD in 2017, and projected to increase to 1195 TPD or 436,175 metric tons annually by 2027 as shown in Figure 3.

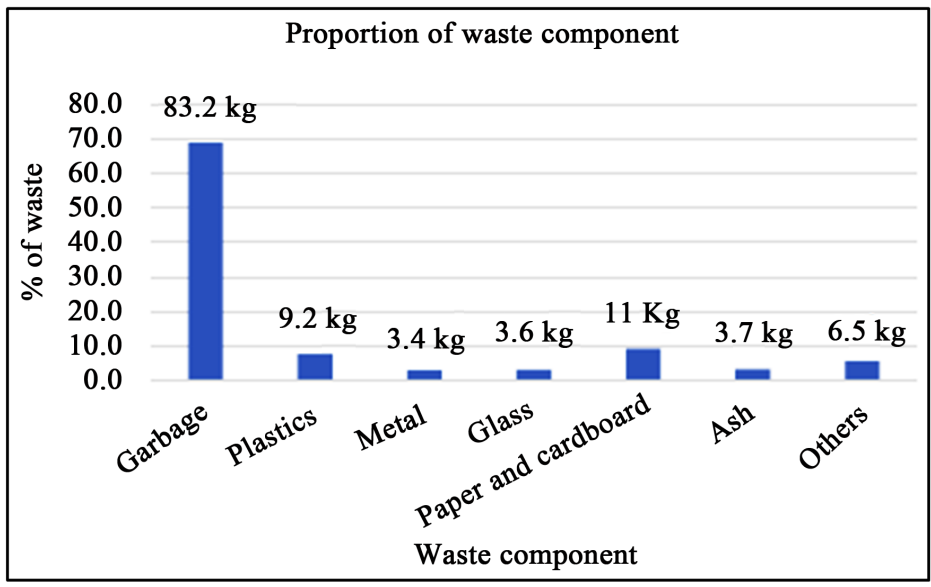

Figure 1. Percentage of waste generation by waste component. 


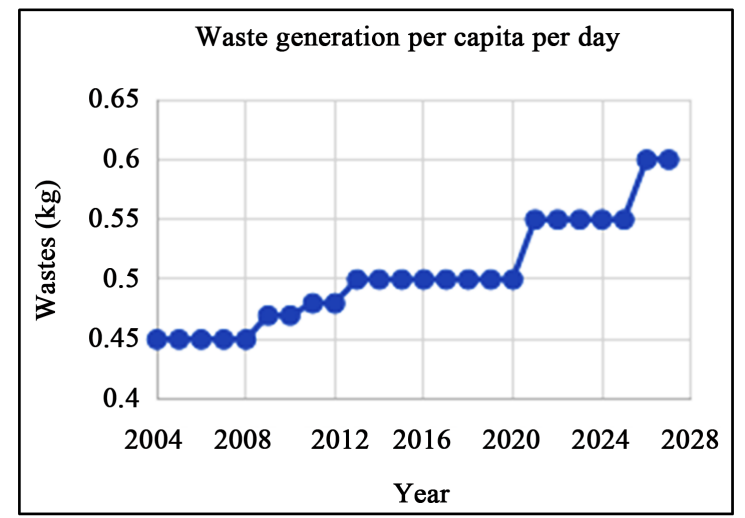

Figure 2. Gradual increment in waste generation per capita.

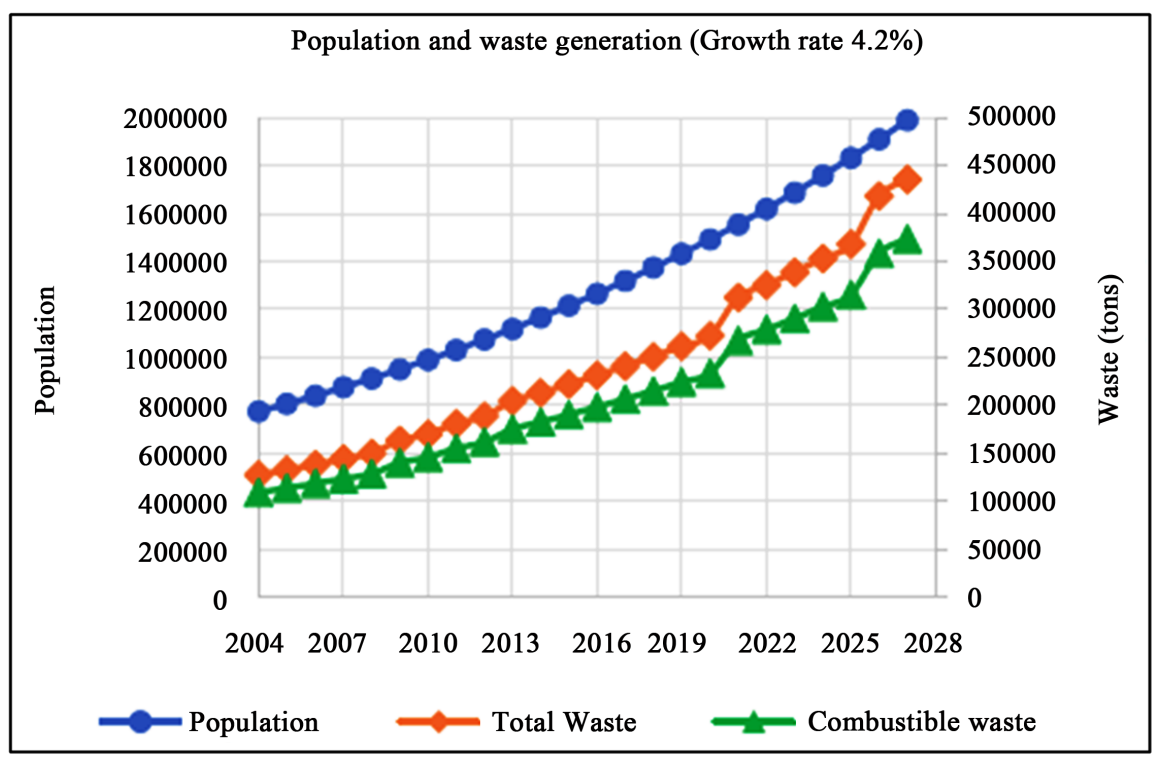

Figure 3. Scenario 1.

Scenario 2 a slower population growth rate of about 3.5\%.

By assuming that after 2017, the average annual growth rate will reduce from $4.2 \%$ to $3.5 \%$, while the trend of waste generation per capita remains the same, the city will experience lower waste generation. Figure 4 shows that by 2027, a total of about 373,405 metric tons of waste will be generated as compared to 436,023 metric tons in Scenario 1.

Scenario 3 a change in the pattern of waste generation per capita.

Waste generation per capita is affected by a change in consumption pattern even if the trend at which the population changes remains the same [26]. Although this trend is expected to increase, a situation was also considered for an opposite trend by assuming that by 2020 the city will start experiencing gradual decline in waste generation per capita as shown in Figure 5, while the growth rate will remain the same as in Scenario 1. Figure 6 shows the projection of waste generation based on this scenario, and by 2027 , a total of 327,018 metric tons of waste will be generated. 


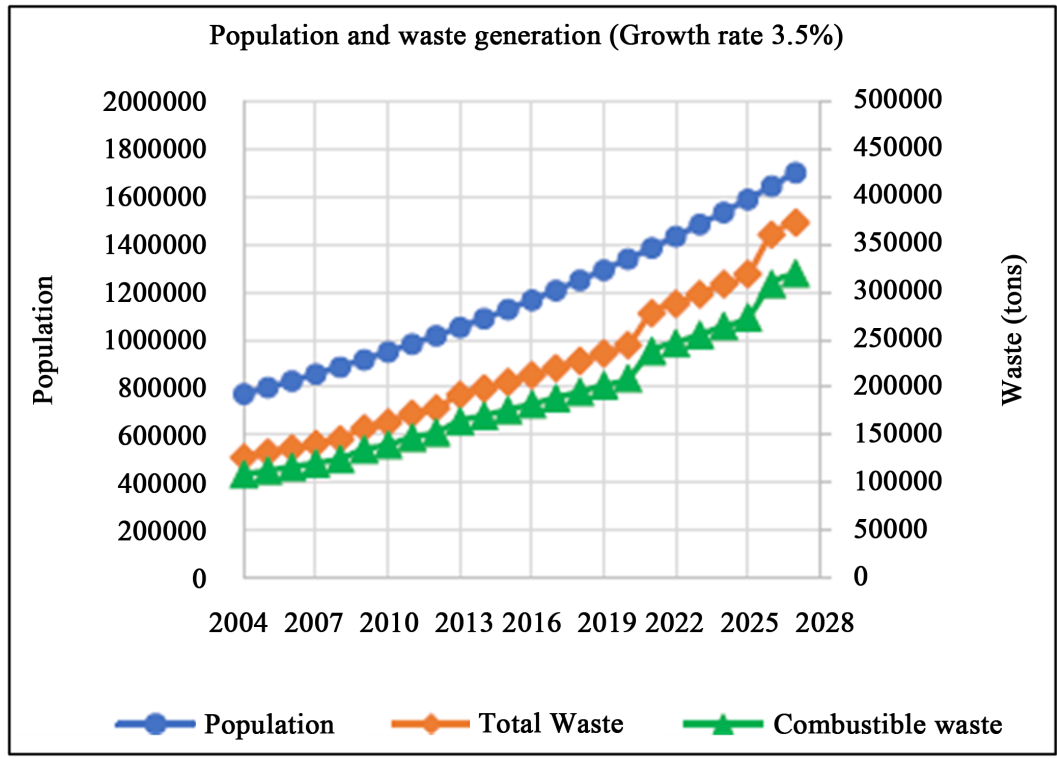

Figure 4. Scenario 2.

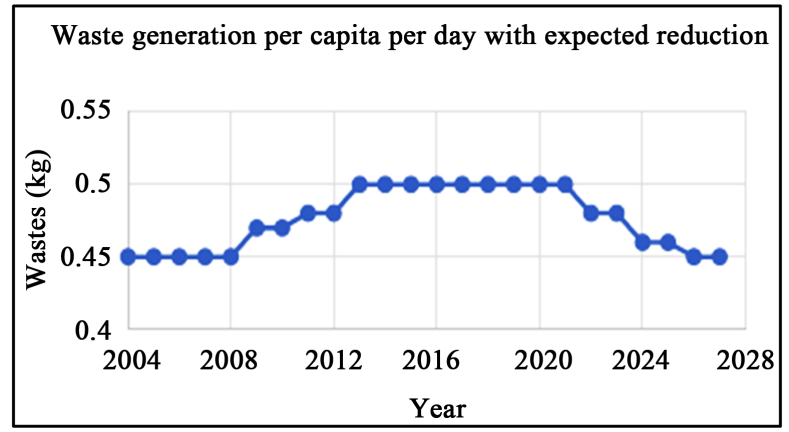

Figure 5. Expected reduction in waste generation per capita after 2020.

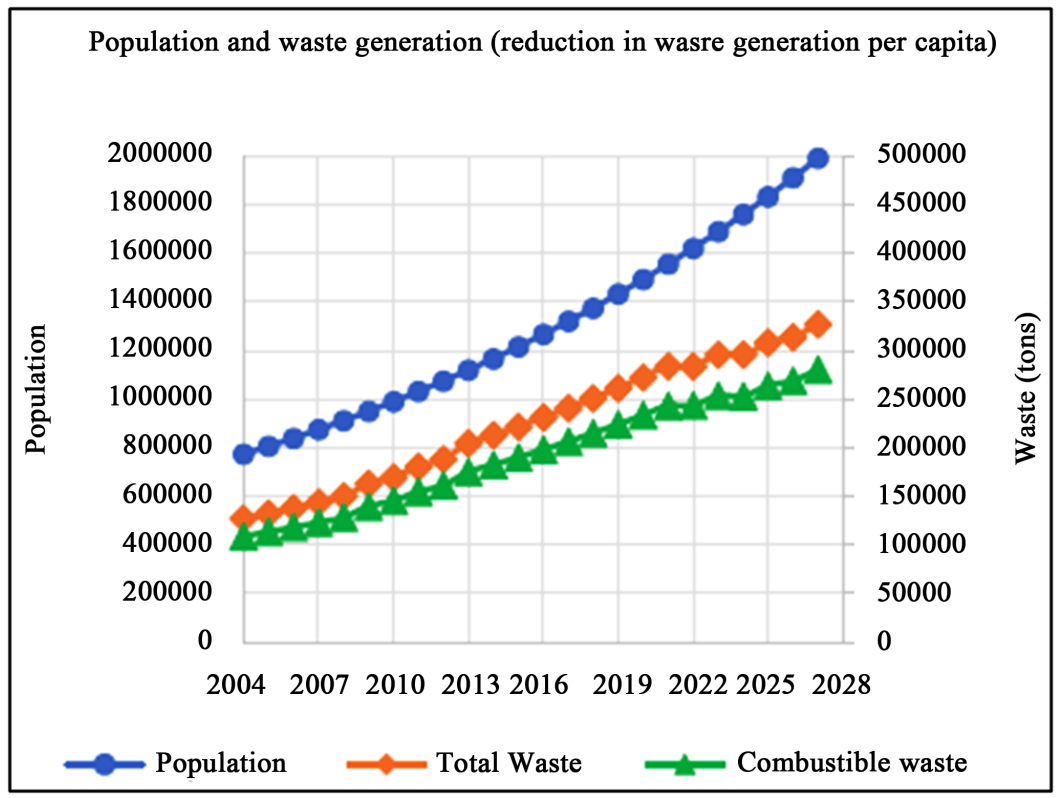

Figure 6. Scenario 3. 
A summary of the results of the estimation of waste generation in Freetown from the three scenarios is presented in Table 2, which revealed that at least 626 metric ton of waste will be generated per day by 2018, and even if only the combustible fraction is considered, about 536 metric tons of waste will be available. This shows that there will be enough waste in Freetown to supply a WtE facility.

\subsection{LCV Estimation}

The overall LCV was calculated as $6.4 \mathrm{MJ} / \mathrm{kg}$ as shown in Table 3. According to a study by [12], the LCV is required to be between 6 and $7 \mathrm{MJ} / \mathrm{kg}$ to be suitable for $\mathrm{WtE}$ recovery by combustion through the use of a steam turbine. Thus, the waste in Freetown will be suitable for WtE recovery by combustion. Although this value is low, it is suitable because there are modern designs that accept wastes with LCV as low as $5.5 \mathrm{MJ} / \mathrm{kg}$. Additionally, this LCV could be improved by reducing the moisture content in the waste stream.

Table 2. Summary of waste generation estimation.

\begin{tabular}{|c|c|c|c|}
\hline \multicolumn{4}{|c|}{ Scenario 1: population growth rate at $4.2 \%$} \\
\hline & 2018 & 2020 & 2027 \\
\hline Waste generation (metric ton per day) & 687 & 746 & 1195 \\
\hline Waste generation (metric ton per year) & 250,755 & 272,290 & 436,175 \\
\hline \multicolumn{4}{|c|}{ Scenario 2: slower population growth rate at $3.5 \%$} \\
\hline & 2018 & 2020 & 2027 \\
\hline Waste generation (metric ton per day) & 626 & 670 & 1023 \\
\hline Waste generation (metric ton per year) & 228,490 & 244,550 & 373,395 \\
\hline \multicolumn{4}{|c|}{ Scenario 3: population growth rate at $4.2 \%$, with reduced waste generation per capita after 2020} \\
\hline & 2018 & 2020 & 2027 \\
\hline Waste generation (metric ton per day) & 687 & 746 & 896 \\
\hline Waste generation (metric ton per year) & 250,755 & 272,290 & 327,040 \\
\hline
\end{tabular}

Table 3. Estimated overall LCV of the waste in free town.

\begin{tabular}{ccccc}
\hline Waste category & $\begin{array}{c}\text { Mean weight } \\
(\mathrm{kg})\end{array}$ & $\begin{array}{c}\text { \% of } \\
\text { total waste }\end{array}$ & $\begin{array}{c}\text { LCV } \\
(\mathrm{MJ} / \mathrm{kg})\end{array}$ & $\begin{array}{c}\text { Weighted LCV } \\
(\mathrm{MJ} / \mathrm{kg})\end{array}$ \\
\hline Organic waste (garbage) & 83.20 & 69.0 & 2.59 & 1.78 \\
Plastic & 9.20 & 7.60 & 24.49 & 1.87 \\
Metal & 3.40 & 2.80 & 0.00 & 0.00 \\
Ash & 3.70 & 3.10 & 0.00 & 0.00 \\
Paper and cardboard & 11.00 & 9.10 & 7.78 & 0.71 \\
Glass & 3.55 & 2.90 & 0.00 & 0.00 \\
Others & 6.50 & 5.40 & 37.19 & 2.01 \\
Total & 120.55 & 100 & & 6.37 \\
\hline
\end{tabular}




\subsection{Energy Potential of Steam Turbine}

The energy conversion potential of the turbine was estimated using the LCV of the waste because the amount of steam energy available is a function of the heating value of the waste. According to [34], the steam energy available is $70 \%$ of the LCV, and the conversion efficiency of waste combustion is about $32 \%$. The estimation of the energy potential of the steam turbine is as shown in Table 4.

For 1 metric ton of mixed municipal solid waste, $398 \mathrm{kWh}$ of electrical energy could be produced, $398 \mathrm{~kW}$ of electrical power for 1 hour or $16.5 \mathrm{~kW}$ of power for 1 day. The impact of this energy potential is dependent on the consumption pattern of the consumer. For instance, if on average the typical consumption per household is $8 \mathrm{kWh}$ per day, 1 ton of waste is capable of providing the energy needs of about 50 households in Freetown.

\section{Discussion}

This study was motivated by the need to address two main problems affecting the people of Freetown, which are unreliable supply of electricity and uncontrolled waste disposal. The result of the study indicating that the waste generated in Freetown is enough and suitable to serve as sustainable fuel for a WtE facility is significant because by investing in this technology these two ageing problems could be solved in a very unique and sustainable manner. There have been some studies on waste recycling in Sierra Leone but there has not been significant academic research on converting waste into energy. Although there has been some private enterprise development in this area, the result of this study is significant because it could be essential in influencing policies and regulations that could lead to more investment in waste-to-energy technologies in the country.

\section{Conclusion and Recommendations}

The study revealed that enough waste is generated in Freetown with an LCV of $6.37 \mathrm{MJ} / \mathrm{kg}$, which makes it suitable for waste-to-energy conversion. This is because the LCV is required to be between 6 and $7 \mathrm{MJ} / \mathrm{kg}$ to be suitable for waste-to-energy recovery by combustion according to [12]. Nonetheless, a key

Table 4. Estimation of the Energy potential of a steam turbine.

\begin{tabular}{cc} 
Parameter & Amount \\
\hline LCV $(\mathrm{MJ} / \mathrm{kg})$ & 70 \\
Steam energy available $(\mathrm{MJ} / \mathrm{kg})$ & 6.4 \\
Heat required to produce $1 \mathrm{kWh}(\mathrm{MJ})$ & 3.48 \\
Conversion efficiency of waste combustion & $32 \%$ \\
Heat rate $(\mathrm{MJ} / \mathrm{kWh})$ & 11.25 \\
Energy potential of steam turbine $(\mathrm{kWh} /$ ton $)$ & 398.2
\end{tabular}


reason for our energy challenges is the lack of commitment by the government to invest in research and development in waste management and energy recovery, and to enact existing policies and formulate new policies that will encourage diversification of the energy mix. Comprehensive energy policies will encourage private and community involvement in the development of the energy sector and suitable environmental policies will help people understand the environmental benefits of transforming their wastes into wealth. This paper has laid a foundation for further research that could lead to the implementation of WtE technologies in urban areas of Sierra Leone, and has also provided reasons for research into the effect of energy and environmental policies on the improvement of access to electricity and keeping our environment clean.

\section{Conflicts of Interest}

The authors declare no conflicts of interest regarding the publication of this paper.

\section{References}

[1] Mustafa, M.Y., Calay, R.K. and Roman, E. (2016) Biogas from Organic Waste-A Case Study. Procedia Engineering, 146, 310-317. https://doi.org/10.1016/j.proeng.2016.06.397

[2] Bosmans, A. and Helsen, L. (2010) Energy from Waste: Review of Thermochemical Technologies for Refuse Derived Fuel (RDF) Treatment. Venice.

[3] Branchini, L. (2015) Waste-to-Energy: Advanced Cycles and New Design Concepts for Efficient Power Plants. Springer International Publishing, New York.

[4] Makarichi, L., Jutidamrongphan, W. and Techato, K. (2018) The Evolution of Waste-to-Energy Incineration: A Review. Renewable and Sustainable Energy Reviews, 91, 812-821. https://doi.org/10.1016/j.rser.2018.04.088

[5] WBG (2019) The World Bank Group-Access to Electricity (\% of Population). https://data.worldbank.org/indicator/EG.ELC.ACCS.ZS

[6] IEA, IRENA, UNSD, WBG, WHO (2019) Tracking SDG 7: The Energy Progress Report 2019. International Bank for Reconstruction and Development, Washington DC.

[7] Stecher, K., Brosowski, A. and Thran, D. (2013) Biomass Potential in Africa. International Renewable Energy Agency (IRENA), Abu Dhabi.

[8] Statistics Sierra Leone (2016) 2015 Population and Housing Census. https://www.statistics.sl/images/StatisticsSL/Documents/final-results -2015 popula $\underline{\text { tion and housing census.pdf }}$

[9] Abarca, L. and de Vreede, V. (2013). http://www.washlearningsl.org/wp-content/uploads/2015/04/Waste-Management-i n-Freetown-Final-report-2013.pdf

[10] Patel, D.A., Gotawala, U.J. and Shah, N.P. (2016) Waste to Energy-Current Practices and Potential in India. Global Research and Development Journal for Engineering, Ahmedabad, 270-273.

http://www.grdjournals.com/conference-proceedings?url=conference-proceedings\& $\underline{\mathrm{id}=\text { GRDCF001 }}$ \&page $=2$ \&per-page $=25$

[11] Kito, J.B. and Stultz, S. (2005) Steam: Its Generation and Uses. 41st Edition, Bab- 
cock \& Wilcox Company, a McDermott Company, Barberton.

[12] Dolgen, D., Sarptas, H., Alpaslan, N. and Kucukgul, O. (2006) Energy Potential of Municipal Solid Wastes. Energy Sources, 27, 1483-1492.

https://doi.org/10.1080/009083190523820

[13] Komilis, D., Evangelou, A., Giannakis, G. and Lymperis, C. (2011) Revisiting the Elemental Composition and the Calorific Value of the Organic Fraction of Municipal Solid Wastes. Waste Management, 32, 372-381.

https://www.researchgate.net/profile/Dimitrios Komilis/publication/51836496 Rev isiting the elemental composition and the calorific value of the organic fracti on of municipal solid wastes/links/0912f50bcea3ab100f000000/Revisiting-the-ele mental-composition

[14] Abdallah, M., Shanableh, A., Arab, M., Shabib, A., Adghim, M. and El-Sherbiny, R. (2019) Waste-to-Energy Potential in Middle Income Countries of MENA Region Based on Multi-Scenario Analysis for Kafr El-Sheik Governorate, Egypt. Journal of Environmental Management, 232, 58-65. https://doi.org/10.1016/j.jenvman.2018.11.029

[15] Moya, D., Aldas, C., Jaramilo, D., Jativa, E. and Kaparaju, P. (2017) Waste-to-Energy Technologies: An Opportunity of Energy Recovery. Energy Procedia, 134, 327-336. https://doi.org/10.1016/j.egypro.2017.09.537

[16] Scarlat, N., Motola, V., Dallemand, J.F., Monforti-Ferrario, F. and Linus, M. (2015) Evaluation of Energy Potential of Municipal Solid Waste from African Urban Areas. Renewable and Sustainable Energy Reviews, 50, 1269-1286. https://doi.org/10.1016/j.rser.2015.05.067

[17] Kemausuor, F., Adaramola, M.S. and Morken, J. (2018) A Review of Commercial Biogas Systems and Lessons for Africa. Energies, 11, 2984. https://doi.org/10.3390/en11112984

[18] Wirba, A.V., Abubakarr Mas'ud, A., Muhammad-Sukki, F., Ahmad, S., Mat Tahar, R., Abdul Rahim, R., Munir, A.B. and Karim, M. (2015) Renewable Energy Potentials in Cameroon: Prospects and Challenges. Renewable Energy, 76, 560-565. https://doi.org/10.1016/j.renene.2014.11.083

[19] Vaish, B., Srivastava, V., Singh, P., Singh, A., Singh, P.K. and Singh, R.P. (2016) Exploring Untapped Energy Potential of Urban Solid Waste. Energy, Ecology and Environment, 1, 323-342. https://doi.org/10.1007/s40974-016-0023-X

[20] Mukherjee, C., Denney, J., Mbonimpa, E.G., Slagley, J. and Bhowmik, R. (2019) A Review on Municipal Solid Waste-to-Energy Trends in the USA. Renewable and Sustainable Energy Reviews, 119, Article ID: 109512. https://doi.org/10.1016/j.rser.2019.109512

[21] CEWEP (2019) Waste-to-Energy Plants in Europe in 2017. http://www.cewep.eu/waste-to-energy-plants-in-europe-in-2017

[22] UN Environment (2019) Ethiopia's Waste-to-Energy Plant Is a First in Africa. https://www.unenvironment.org/news-and-stories/story/ethiopias-waste-energy-pla nt-first-africa

[23] Cloete, K. (2017) Ground-Breaking Waste-to-Energy Plant Opens in Cape Town. http://www.engineeringnews.co.za/article/ground-breaking-waste-to-energy-plantopens-in-cape-town-2017-01-24

[24] Government Europa (2018) Waste to Energy Initiatives: The Next Step toward a Circular Economy. https://www.governmenteuropa.eu/waste-to-energy-initiatives-circular-economy/9 
$\underline{1567}$

[25] WRAP (2019) WRAP and the Circular Economy.

http://www.wrap.org.uk/about-us/about/wrap-and-circular-economy

[26] Hoornweg, D. and Bhada-Tata, P. (2012) What a Waste: A Global Review of Solid Waste Management.

https://siteresources.worldbank.org/INTURBANDEVELOPMENT/Resources/3363 87-1334852610766/What a Waste2012 Final.pdf

[27] Sood, D. (2004) Solid Waste Management Study for Freetown, Sierra Leone. http://documents.worldbank.org/curated/en/326861468760542281/pdf/E9421Sierra 0Leone0Power0and0Water.pdf

[28] Sankoh, F.P., Yan, X. and Tran, Q. (2014) Assessment of Solid Waste Management in Freetown, Sierra Leone towards Sustainable Development. Journal of Applied Sciences, 14, 2909-2924. https://doi.org/10.3923/jas.2014.2909.2924

[29] Aga, O., Ouda, O.K. and Raza, S.A. (2014) Investigating Waste to Energy Potential in the Eastern Region of Saudi Arabia. 2nd Renewable Energy for Developing Countries, Beirut, 26-27 November 2014, 7-11. https://doi.org/10.1109/REDEC.2014.7038522

[30] Sebastian, R.M. and Alappat, B. (2016) Thermal Properties of Indian Municipal Solid Waste over the Past, Present and Future Years and Its Effect on Thermal Waste to Energy Facilities. Civil Engineering and Urban Planning. An International Journal, 3, 97-106.

[31] Li, X., Zhang, C., Li, Y. and Zhi, Q. (2016) The Status of Municipal Solid Waste Incineration (MSWI) in China and Its Clean Development. Energy Procedia, 104, 498-503. https://doi.org/10.1016/j.egypro.2016.12.084

[32] Singh, R.P., Tyagi, V.V., Allen, T., Ibrahim, H.M. and Kothari, R. (2011) An Overview for Exploring the Possibilities of Energy Generation from Municipal Solid Waste (MSW) in Indian Scenario. Renewable and Sustainable Energy Reviews, 15, 4797-4808. https://doi.org/10.1016/j.rser.2011.07.071

[33] WBGa (2019) The World Bank in Sierra Leone. https://www.worldbank.org/en/country/sierraleone/overview\#1

[34] Gupta, S. and Mishra, R.S. (2015) Estimation of Electrical Energy Generation from Waste to Energy Using Incineration Technology. International Journal of Advanced Research and Innovation, 3, 631-634. 